Bull. Fac. Agric., Cairo Univ., 69: 43-52 (2018).

\title{
AMELIORATION OF WATER STRESS EFFECT ON SORGHUM PLANT GROWTH AND WATER USE EFFICIENCY BY APPLICATION OF POTASSIUM SILICATE AND SALICYLIC ACID
}

(Received: 27.2.2018)

\author{
By \\ S. A. Abdeen and A. G. A. Mancy \\ Soils and Water Department, Faculty of Agriculture, Al-Azhar University, Cairo, Egypt.
}

\begin{abstract}
The present study was carried out during the summer season of 2017 to ameliorate the effect of water stress on growth parameters of sorghum plant, macronutrient uptake, water use efficiency and dry matter by addition of potassium silicate and salicylic acid as foliar applications. Two pot experiments were conducted at the farm of the Faculty of Agriculture, Al-Azhar University, Nasr city, Cairo, Egypt. The two factorial experiments were arranged in a randomized complete block design with 9 treatments and three replicates per treatment in each experiment. In the first experiment, foliar spray of potassium silicate ( 1 and $2 \%$ ) and untreated as the control were applied under 100, 75 and 50 $\%$ of field capacity (FC). In the second experiment, foliar application of salicylic acid (100 and 200 ppm) and untreated as the control were applied under 100, 75 and 50\% of field capacity (FC). Potassium silicate and salicylic acid were sprayed on the vegetative growth of sorghum plants four times every two weeks, after ten days of planting during the period of the experiment (60 days). The results showed that there were significant increases in the growth parameters, i.e. plant height, stem diameter, fresh and dry weight of sorghum plants as a result of foliar application by potassium silicate and salicylic acid under water stress compared with the control. It is clear that, potassium silicate was more effective than salicylic acid in improving all growth parameters. Decreasing water availability generally results in reduced the total nutrient concentration in sorghum plants, the most affected was $\mathrm{P}$ and $\mathrm{K}$ under all levels of moisture content. But nitrogen content decreased at $75 \% \mathrm{FC}$, and increased at $50 \%$ FC. Also, NPK uptake significantly increased with increasing foliar applications of potassium silicate and salicylic acid under all levels of moisture content compared with the control. The data clearly reveal that foliar applications of potassium silicate had the highest significant water use efficiency compared to the control. Also, salicylic acid gave a positive effect on water use efficiency.
\end{abstract}

Key words: water stress, macronutrients uptake, sorghum bicolor L. Moench, growth parameters.

\section{INTRODUCTION}

Water stress is one of the most important environmental stresses that could influence growth and physiological characteristics of plants. Decreased water availability generally results in reduced growth and final yield in crop plants (Du et al., 2010). Drought stress can damage plant cell membranes, and cell wall architecture, as well as inhibit photosynthesis and cell division (Taiz and Zeiger, 2006). Knowledge of the biochemical responses to drought is essential for a holistic perception of plant tolerance mechanisms to water limited conditions in higher plants (Ruppenthal et al., 2016).

Application of plant hormones has been found to ameliorate the negative effects of various abiotic stresses. Also, the supplementation of silicon to the plants plays a significant role in improving growth, and amelioration of abiotic and biotic stresses. Unfortunately, the significance of silicon (Si) nutrition in crop production and mitigation of abiotic and biotic stresses remain unexplored (Chanchal et al., 2016). Similarly, potassium (K) is the most mobile plant nutrient and plays a role in osmotic regulation and enhances drought tolerance by maintaining water balance (Beg and Sohrab, 2012). Potassium silicate is a source of highly soluble potassium and silicon, thus it is used in agricultural production system (Tarabih et al., 2014). Silicon is not considered an 
essential element for plant growth but its beneficial effects are normally observed under stress conditions. These beneficial effects are attributed to $\mathrm{Si}$ deposited in the cell wall of various plant organs (Ma and Yamaji, 2006). In addition Hattori et al. (2005) observed that 1.66 $\mathrm{mM} \mathrm{K} \mathrm{K}_{2} \mathrm{SiO}_{3}$ ameliorated the decrease in dry weight of sorghum plants under drought stress conditions. Silicon application may be useful to improve the drought tolerance of sorghum through the enhancement of water uptake ability (Ahmed et al., 2011).

Moreover, Sonobe et al., (2009) found that $50 \mathrm{ppm}$ silicon ameliorated dry mass reduction in hydroponic sorghum exposed to polyethylene glycol water stress. Some positive effects of $\mathrm{Si}$ application have been attributed to proper maintenance of water in leaves, thus preventing destruction of photosynthetic process and chlorophyll in leaves (Mali and Arey, 2008). Generally, beneficial effects of silicon (Si) in the plant growth under conditions of drought stress have been associated with uptake and accumulation ability of elements by different species of plants.

Salicylic acid (SA) has a key role in many physiological processes of plants and stimulates specific responses against various biotic and abiotic stresses (Khatiby et al., 2016). SA is a phenolic compound synthesized throughout the plant kingdom via the phenylpropanoid pathway. Considerable interests have been focused on SA due to its ability to induce a protective effect under stress. SA significantly alleviated growth inhibition induced by drought and manifested by less decreases of fresh and dry mass, plant height, root length (Kang et al., 2013). Salicylic acid is considered to be an endogenous growth regulator of phenolic nature that enhanced leaf area and dry mass production in corn and soybean. SA as a potent signaling molecule in plants is involved in eliciting specific responses to biotic and abiotic stresses (Nikju 2017). Finally, application of potassium silicate and salicylic acid is considered one of the methods used to reduce the deleterious effects of water stress. The present experiment was conducted to ameliorate the effect of drought stress on sorghum plant growth, water use efficiency and nutrient uptake through foliar application of potassium silicate and salicylic acid.

\section{MATERIALS AND METHODS}

Two pot experiments were conducted in order to study the effect of potassium silicate and salicylic acid under water stress on sorghum plant growth, nutrient uptake and water use efficiency, at the farm of the Faculty of Agriculture, Al- Azhar University, Nasr city, Cairo, Egypt. The two experiments were conducted during the summer season of 2017. Factorial experiments were arranged in a randomized complete block design with 9 treatments and three replicates per treatment for each experiment. The treatments were as follows: water stress, including three levels of field capacity (100, 75 and $50 \%)$, and foliar application of potassium silicate $(1,2 \%)$ in the $1^{\text {st }}$ experiment. Foliar spray application of salicylic acid (100, $200 \mathrm{ppm})$ was compared with the control (sprayed distilled water under 100,75 and $50 \%$ of field capacity) in the $2^{\text {nd }}$ experiment. All foliar sprayings were conducted early in the morning (7.30- $8.30 \mathrm{am})$. Foliar sprays were applied four times every two weeks after ten days of planting in throughout the experiment (60 days), plastic pots filled with 5 $\mathrm{kg}$ sandy soil the soil were mixed with compost (70g/pot) before planting. After thinning each pot containing 10 seeds of sorghum (Sorghum bicolor (L.) Moench). Ammonium nitrate, super phosphate and potassium sulfate fertilizers were applied according to the general recommendation dose of the Ministry of Agric. After 60 days from planting, sorghum shoots of each treatment were cut just one $\mathrm{cm}$ above the soil surface and prepared for analysis. The characteristics of the investigated soil, i.e. particle size distribution, soil $\mathrm{pH}, \mathrm{EC}$, soluble cations and anions, OM, CEC, available N, P, K were determined (Page et al.,1982) and Klute (1986). N, P and K were estimated in the plant digest according to Cottenie et al., (1982). Stem diameter $(\mathrm{cm})$ was measured by using a vernier (caliper). Water use efficiency for dry biomass $\left(\mathrm{kg} / \mathrm{m}^{3}\right)=$ Total Biomass $(\mathrm{kg}) /$ water applied $\left(\mathrm{m}^{3}\right)$ at different levels of the field capacity according to Stanhill (1987). Statistical analysis was carried out by MSTATC and comparisons of means were made using LSD test according to Snedecor and Cocharn (1980). The composition of potassium liquid silicate $\left(\mathrm{K}_{2} \mathrm{SiO}_{3}\right)$ was: $26.6 \% \mathrm{~K}_{2} \mathrm{O}$ and $10.4 \% \mathrm{SiO}_{3}$. The chemical and physical analyses of the experimental soil and compost are shown in Table (1). 
Table (1): Some physical and chemical properties of the studied soil and compost.

\begin{tabular}{|c|c|c|}
\hline \multicolumn{2}{|c|}{ Soil } & \multirow{2}{*}{$\begin{array}{c}\text { Compost } \\
\text { Value }\end{array}$} \\
\hline Parameter & Value & \\
\hline \multicolumn{3}{|l|}{ Physical properties } \\
\hline Sand $\%$ & 78.5 & - \\
\hline Silt \% & 13.5 & - \\
\hline Clay \% & 8.0 & - \\
\hline Textural class & Loamy sand & - \\
\hline Field capacity (F C) \% & 11.50 & - \\
\hline Bulk density $\mathrm{Mg} \mathrm{m}^{-3}$ & 1.37 & 0.70 \\
\hline \multicolumn{3}{|l|}{ Chemical properties } \\
\hline $\mathrm{pH}$ & 7.95 & 6.67 \\
\hline $\begin{array}{l}\text { EC dS } \mathrm{m}^{-1}(1: 2.5) \text { in soil and } \\
(1: 10) \text { in compost }\end{array}$ & 1.20 & 3.60 \\
\hline $\mathrm{OM} \%$ & 0.41 & 3.56 \\
\hline CEC cmolc kg ${ }^{-1}$ & 3.11 & - \\
\hline \multicolumn{3}{|l|}{ Soluble ions meq/100g soil } \\
\hline $\mathrm{Ca}^{++}$ & 0.23 & - \\
\hline $\mathrm{Mg}^{++}$ & 0.36 & - \\
\hline $\mathrm{Na}^{+}$ & 2.06 & - \\
\hline $\mathrm{K}^{+}$ & 0.19 & - \\
\hline $\mathrm{CO}_{3}=$ & 0.00 & - \\
\hline $\mathrm{HCO}_{3}^{-}$ & 0.50 & - \\
\hline $\mathrm{Cl}^{-}$ & 1.63 & - \\
\hline $\mathrm{SO}_{4}^{=}$ & 0.71 & - \\
\hline \multicolumn{2}{|l|}{$\begin{array}{l}\text { Available } \\
\text { macronutrients mg/kg }\end{array}$} & Total macronutrients \% \\
\hline $\mathrm{N}$ & 41.00 & 1.95 \\
\hline $\mathrm{P}$ & 12.40 & 0.66 \\
\hline $\mathrm{K}$ & 68.50 & 1.65 \\
\hline
\end{tabular}

\section{RESULTS AND DISCUSSION}

3.1. Effect of potassium silicate and salicylic acid on growth parameters of sorghum plants

The results presented in Table (2) showed that there was a significant increase in the growth parameters, i.e. plant height, stem diameter, fresh and dry weight of sorghum plants as a result of foliar spray by potassium silicate and salicylic acid under water stress compared with the control. In general, potassium silicate was more effective than salicylic acid for improving all growth parameters. This may be due to the effect of $\mathrm{K}$ 's role on the response of plants to drought stress. These results are in good agreement with those reported by $\mathrm{Abd} \mathrm{El-}$ Wahed et al. (2006).

The highest value of shoot length (135.2 $\mathrm{cm})$ was recorded at $1 \%$ potassium silicate under $100 \%$ of FC compared with other treatments. The presence of silicon in sorghum plant had an improving effect on shoot growth. This might be due to the fact that potassium affects photosynthesis at various levels (Hattori et al., $2005)$. In addition, $2 \%$ potassium silicate gave a good result at $75 \%$ of $\mathrm{FC}$, where the highest value $(134.4 \mathrm{~cm})$ was recorded compared with other treatments. The increment in vegetative growth of plants sprayed with potassium silicate may be due to the role of potassium in plant nutrition, i.e. promotion of enzymes activity. The results confirm that soil potassium content is not enough to the fulfill the needs of some plants. In this concern, Sangakkara et al., (2001) attributed the increase in the growth to the role of $\mathrm{K}$ in biochemical pathways in plants. Also, shoot length increased by the addition of salicylic acid. In this concern, Singh and Usha (2003) suggested that the promotive effect of SA under drought stress may be related to the induction of antioxidant responses which protect plant from damage. The highest value (131.50) was recorded at $200 \mathrm{ppm}$ under $100 \%$ FC compared with the control.

Concerning the effect of potassium silicate and salicylic acid on stem diameter, the data cleared that, there was a positive effect for increasing stem diameter. For potassium silicate treatment, the highest value $(15.56 \mathrm{~mm})$ was recorded at $1 \%$ under 100 of FC. While, the 
Table (2): Effect of potassium silicate and salicylic acid on the growth parameters of sorghum plant under water stress.

\begin{tabular}{|c|c|c|c|c|c|c|}
\hline \multicolumn{3}{|c|}{$1^{\text {st }}$ experiment } & \multicolumn{4}{|c|}{ Growth parameters } \\
\hline \multicolumn{2}{|c|}{ Treatments } & $\begin{array}{l}\text { Moisture } \\
\text { content \% }\end{array}$ & $\begin{array}{c}\text { Shoot length } \\
\text { cm }\end{array}$ & $\begin{array}{c}\text { Stem } \\
\text { diameter } \\
\text { mm }\end{array}$ & $\begin{array}{c}\text { Fresh } \\
\text { weight } \\
\text { g/plant }\end{array}$ & $\begin{array}{c}\text { Dry } \\
\text { weight } \\
\text { g/plant }\end{array}$ \\
\hline \multirow{4}{*}{\multicolumn{2}{|c|}{ Control }} & 100 & 128.80 & 13.23 & 11.85 & 2.78 \\
\hline & & 75 & 124.20 & 12.50 & 10.78 & 2.26 \\
\hline & & 50 & 111.50 & 12.10 & 10.00 & 1.93 \\
\hline & & Mean & 121.50 & 12.61 & 10.88 & 2.32 \\
\hline \multirow{8}{*}{$\begin{array}{l}\text { Potassium } \\
\text { silicate \% }\end{array}$} & \multirow{4}{*}{1} & 100 & 135.20 & 15.56 & 13.56 & 3.85 \\
\hline & & 75 & 132.80 & 15.00 & 12.95 & 3.58 \\
\hline & & 50 & 120.30 & 12.32 & 11.02 & 2.25 \\
\hline & & Mean & 129.43 & 14.29 & 12.51 & 3.23 \\
\hline & \multirow{4}{*}{2} & 100 & 131.00 & 14.64 & 12.80 & 3.34 \\
\hline & & 75 & 135.00 & 15.50 & 13.60 & 3.95 \\
\hline & & 50 & 125.30 & 13.41 & 11.30 & 2.54 \\
\hline & & Mean & 130.43 & 14.52 & 12.57 & 3.28 \\
\hline \multirow{3}{*}{ LSD at $5 \%$} & \multicolumn{2}{|c|}{ Potassium silicate (A) } & 1.33 & 0.81 & 0.59 & 0.02 \\
\hline & \multicolumn{2}{|c|}{ Moisture content (B) } & 0.83 & 0.72 & 0.54 & 0.11 \\
\hline & \multicolumn{2}{|c|}{$\mathbf{A B}$} & 1.44 & 1.25 & 0.94 & 0.19 \\
\hline \multicolumn{3}{|c|}{$2^{\text {nd }}$ experiment } & & 1300 & 1250 & 305 \\
\hline \multirow{8}{*}{$\begin{array}{c}\text { Salicylic } \\
\text { acid } \\
\text { ppm }\end{array}$} & \multirow{4}{*}{100} & 100 & 130.60 & 13.90 & 12.50 & 3.05 \\
\hline & & 75 & 125.30 & 12.80 & 12.50 & 2.63 \\
\hline & & 50 & 119.40 & 12.00 & 10.10 & 2.36 \\
\hline & & Mean & 125.10 & 12.90 & 11.70 & 2.68 \\
\hline & \multirow{4}{*}{200} & 100 & 131.50 & 14.95 & 12.80 & 3.10 \\
\hline & & 75 & 129.40 & 12.94 & 12.00 & 2.60 \\
\hline & & 50 & 118.00 & 11.70 & 10.30 & 1.96 \\
\hline & & Mean & 126.30 & 13.20 & 11.70 & 2.55 \\
\hline \multirow{3}{*}{ LSD at $5 \%$} & \multicolumn{2}{|c|}{ Salicylic acid (A) } & 0.82 & 0.78 & 0.04 & 0.05 \\
\hline & \multicolumn{2}{|c|}{ Moisture content (B) } & 0.56 & 0.57 & 0.06 & 0.07 \\
\hline & \multicolumn{2}{|c|}{$\mathbf{A B}$} & 0.97 & 0.98 & 0.11 & 0.12 \\
\hline
\end{tabular}

lowest value $(12.10 \mathrm{~mm})$ was recorded at the control under $50 \%$ of FC. In this respect, increased silicon application can enhance growth and development of sorghum and it can be recommended as supplemental fertilizer to enhance drought tolerance (Mukhtar et al., 2011).

Also, salicylic acid had a significant effect on stem diameter. The highest value $(14.95 \mathrm{~mm})$ was at $200 \mathrm{ppm}$ under $100 \mathrm{FC}$. While, the lowest value $(11.7 \mathrm{~mm})$ was at $200 \mathrm{ppm}$ under $50 \%$ FC. These results are in agreement with those reported by Maghsoudi et al. (2015). On the contrary, Ruppenthal et al. (2016) found that the plant growth of soybean was negatively affected by the presence of $\mathrm{Si}$ under well-irrigated conditions. It can be noticed that the increment depends on the kind of plant and moisture content.

Fresh and dry weights are improved by potassium silicate and salicylic acid. The highest values were 13.60 and $3.95 \mathrm{~g} / \mathrm{plant}$, respectively, at $2 \%$ applications of potassium silicate under $75 \%$ FC, compared with the control. While, the lowest values were 10 and $1.93 \mathrm{~g} / \mathrm{plant}$, respectively in the control under $50 \%$ of FC. In general, applied potassium silicate under water stress gave a significant improvement in fresh and dry weights of sorghum plants. In this respect, Vaculik et al. (2009) found that different concentrations of silicon had positive effects on most growth parameters of maize plants compared with the control. Also, foliar application of salicylic acid gave an increase in fresh and dry weights especially at $200 \mathrm{ppm}$ under $100 \%$ FC. Silicon application had been reported to alleviate the decrease in dry matter in various species of cereals (Liang et al., 1996). The highest values of fresh and dry weights $(12.8$ and $3.1 \mathrm{~g} / \mathrm{plant}$, respectively) were recorded compared with the control. SA significantly alleviated the growth inhibition 
induced by drought (Kang et al., 2013). In general, the effect of potassium silicate and salicylic acid on the growth petameters of sorghum plants were arranged as follows: $2 \%$ potassium silicate $>1 \%$ potassium silicate $>200$ ppm salicylic acid $>100$ ppm salicylic acid $>$ the control.

\subsection{Effect of potassium silicate and salicylic} acid on NPK content of sorghum plant under water stress

Data presented in Table (3) represent the effect of potassium silicate and salicylic acid under water stress on NPK content for sorghum plants. Decreasing water availability generally resulted in limited total nutrient concentrations in sorghum plants, where the most effect was $\mathrm{P}$ and $\mathrm{K}$ at all levels of moisture content. But nitrogen content decreased at $75 \% \mathrm{FC}$, then increased again at 50\% FC. In this respect, Alam (1994) found that the plants grown under water deficit have high $\mathrm{N}$ concentration because the free amino acids accumulation are not synthesized into protein.

It is obvious that the increase nitrogen, phosphorus and potassium content in sorghum plants were significantly influenced in the treatments. For potassium silicate; the minimum nitrogen content $(3.24 \%)$ was recorded by $1 \%$ potassium silicate under $50 \%$ FC. While, the maximum value $(3.8 \%)$ was recorded at $2 \%$ under $75 \%$ FC. On the other hand, phosphorus and potassium increased with increasing potassium silicate and moisture content. In this concern, Marschner (2012) found that phosphorus concentration increased by foliar applications of potassium silicate comparing with the control. The lowest values $(0.36 \%$ and $2.4 \%$ ) were recorded at $1 \%$ under $50 \% \mathrm{FC}$, respectively. While, the highest values were 0.54 and $3.25 \%$, respectively at $2 \%$ under $100 \%$ FC. These observations indicate that adequate $\mathrm{K}$ nutrition can improve drought tolerance of

Table (3): Effect of potassium silicate and salicylic acid on NPK content of sorghum plant under water stress.

\begin{tabular}{|c|c|c|c|c|c|}
\hline \multicolumn{3}{|c|}{$\mathbf{1}^{\text {st }}$ experiment } & \multicolumn{3}{|c|}{ Macronutrients content \% } \\
\hline Treat & & $\begin{array}{r}\text { Moisture } \\
\text { content } \%\end{array}$ & $\mathbf{N}$ & $\mathbf{P}$ & $\mathbf{K}$ \\
\hline \multirow{4}{*}{\multicolumn{2}{|c|}{ Control }} & 100 & 3.43 & 0.46 & 2.87 \\
\hline & & 75 & 2.81 & 0.40 & 2.40 \\
\hline & & 50 & 3.00 & 0.26 & 1.80 \\
\hline & & Mean & 3.17 & 0.37 & 2.36 \\
\hline \multirow{8}{*}{$\begin{array}{l}\text { Potassium } \\
\text { silicate \% }\end{array}$} & \multirow{4}{*}{1} & 100 & 3.60 & 0.49 & 3.10 \\
\hline & & 75 & 3.66 & 0.43 & 2.80 \\
\hline & & 50 & 3.24 & 0.36 & 2.40 \\
\hline & & Mean & 3.50 & 0.43 & 2.77 \\
\hline & \multirow{4}{*}{2} & 100 & 3.60 & 0.54 & 3.25 \\
\hline & & 75 & 3.80 & 0.50 & 3.20 \\
\hline & & 50 & 3.50 & 0.41 & 2.50 \\
\hline & & Mean & 3.63 & 0.48 & 2.98 \\
\hline \multirow{3}{*}{ LSD at $5 \%$} & \multicolumn{2}{|c|}{ Potassium silicate (A) } & 0.12 & 0.008 & 0.10 \\
\hline & \multicolumn{2}{|c|}{ Moisture content (B) } & 0.12 & 0.021 & 0.06 \\
\hline & & $\mathrm{AB}$ & 0.21 & 0.037 & 0.09 \\
\hline \multicolumn{3}{|c|}{$2^{n d}$ experiment } & & & \\
\hline \multirow{8}{*}{$\begin{array}{c}\text { Salicylic } \\
\text { acid } \\
\text { ppm }\end{array}$} & \multirow{4}{*}{100} & 100 & 3.50 & 0.50 & 2.90 \\
\hline & & 75 & 3.22 & 0.43 & 2.81 \\
\hline & & 50 & 2.85 & 0.40 & 2.40 \\
\hline & & Mean & 3.19 & 0.44 & 2.70 \\
\hline & \multirow{4}{*}{200} & 100 & 3.63 & 0.50 & 3.11 \\
\hline & & 75 & 3.60 & 0.46 & 2.84 \\
\hline & & 50 & 3.20 & 0.40 & 2.60 \\
\hline & & Mean & 2.48 & 0.45 & 2.85 \\
\hline \multirow{3}{*}{ LSD at $5 \%$} & \multicolumn{2}{|c|}{ Salicylic acid (A) } & 0.16 & 0.02 & 0.09 \\
\hline & \multicolumn{2}{|c|}{ Moisture content (B) } & 0.08 & 0.02 & 0.06 \\
\hline & \multicolumn{2}{|c|}{$\mathrm{AB}$} & 0.15 & 0.03 & 0.11 \\
\hline
\end{tabular}


sorghum (Asgharipour and Heidari 2011).

Meanwhile, it is clear that salicylic acid treatment gave a significant effect on NPK content of sorghum plants. The maximum values of NPK content $(3.5,0.5$ and $2.9 \%$, respectively) were recorded by salicylic acid at 200 ppm treatment under $100 \%$ FC. While, the minimum values (3.2,0.4 and 2.6) were recorded by $100 \mathrm{ppm}$ foliar application of salicylic acid under $50 \%$ FC. In this concern, Simaei et al. (2012) reported that salicylic acid plays an important role in the regulation of some physiological processes and nutrients in soybean plants.

3.3. NPK uptake of sorghum plant as affected by Potassium silicate and salicylic acid under water stress.

The data presented in Table (4) indicate the effect of potassium silicate and salicylic acid on NPK uptake by sorghum plants under water stress. In general, NPK uptake decreased with increasing drought stress. The highest values $(95.35,12.79$ and $79.79 \mathrm{mg} /$ plant $)$ were recorded at $100 \%$ FC. While, the lowest values (54.23, 5.02 and $34.74 \mathrm{mg} /$ plant) were recorded at $50 \%$ FC. Drought is a significant limiting factor for plant growth through reduced water absorption and nutrient uptake (Du et al., 2010).

On the other hand, all rates of potassium silicate and salicylic acid showed a significant increase in nutrients uptake by sorghum plants as compared to the control. Salicylic acid plays diverse physiological roles in plants including plant growth and nutrient uptake (Janda et al., 2007). It is clear that NPK uptake increased with increasing foliar application of potassium silicate and salicylic acid under all levels of moisture content compared with the control. For potassium silicate treatment, the highest values of NPK uptake (150, 10, 19.75 and 126.4 $\mathrm{mg} / \mathrm{plant}$, respectively) were recorded by potassium silicate at $2 \%$ under $75 \%$ FC. This can

Table (4): Effect of potassium silicate and salicylic acid on NPK uptake by sorghum plants under water stress.

\begin{tabular}{|c|c|c|c|c|c|}
\hline \multicolumn{3}{|c|}{$1^{\text {st }}$ experiment } & \multicolumn{3}{|c|}{ Macronutrients uptake mg/plant } \\
\hline Treatn & & $\begin{array}{l}\text { Moisture } \\
\text { content \% }\end{array}$ & $\mathbf{N}$ & $\mathbf{P}$ & $\mathbf{K}$ \\
\hline \multirow{4}{*}{\multicolumn{2}{|c|}{ Control }} & 100 & 95.35 & 12.79 & 79.79 \\
\hline & & 75 & 63.51 & 9.04 & 54.24 \\
\hline & & 50 & 57.9 & 5.02 & 34.74 \\
\hline & & Mean & 72.25 & 8.95 & 56.26 \\
\hline \multirow{8}{*}{$\begin{array}{l}\text { Potassium } \\
\text { silicate \% }\end{array}$} & \multirow{4}{*}{1} & 100 & 111.24 & 15.14 & 119.35 \\
\hline & & 75 & 96.62 & 11.35 & 100.24 \\
\hline & & 50 & 72.90 & 8.10 & 54.00 \\
\hline & & Mean & 93.59 & 11.53 & 91.20 \\
\hline & \multirow{4}{*}{2} & 100 & 120.24 & 18.04 & 108.55 \\
\hline & & 75 & 150.10 & 19.75 & 126.4 \\
\hline & & 50 & 88.90 & 10.41 & 63.50 \\
\hline & & Mean & 119.75 & 16.07 & 99.84 \\
\hline \multirow{3}{*}{ LSD at $5 \%$} & \multicolumn{2}{|c|}{ Potassium silicate (A) } & 3.95 & 0.70 & 1.32 \\
\hline & \multicolumn{2}{|c|}{ Moisture content (B) } & 1.45 & 1.12 & 1.94 \\
\hline & \multicolumn{2}{|c|}{$\mathrm{AB}$} & 2.52 & 1.94 & 3.37 \\
\hline \multicolumn{3}{|c|}{$2^{n d}$ experiment } & \multirow{2}{*}{106.75} & \multirow{2}{*}{15.25} & \multirow{2}{*}{88.45} \\
\hline \multirow{8}{*}{$\begin{array}{c}\text { Salicylic acid } \\
\text { ppm }\end{array}$} & \multirow{4}{*}{100} & 100 & & & \\
\hline & & 75 & 84.69 & 11.31 & 73.90 \\
\hline & & 50 & 67.26 & 9.44 & 56.64 \\
\hline & & Mean & 86.23 & 12.00 & 72.10 \\
\hline & \multirow{4}{*}{200} & 100 & 117.61 & 16.20 & 100.76 \\
\hline & & 75 & 106.56 & 13.62 & 84.06 \\
\hline & & 50 & 62.72 & 7.84 & 50.96 \\
\hline & & Mean & 95.63 & 12.55 & 78.59 \\
\hline \multirow{3}{*}{ LSD at $5 \%$} & \multicolumn{2}{|c|}{ Salicylic acid (A) } & 3.85 & 0.41 & 1.54 \\
\hline & \multicolumn{2}{|c|}{ Moisture content (B) } & 2.13 & 0.67 & 0.62 \\
\hline & \multicolumn{2}{|c|}{$\mathbf{A B}$} & 3.70 & 1.16 & 1.07 \\
\hline
\end{tabular}


has a dual benefit by improving the physiological performance of supply of $\mathrm{K}$ nutrient to plants (Raza et al., 2013), while, the lowest values (72.9, 8.1 and $54 \mathrm{mg} /$ plant, respectively) were recorded by potassium silicate at $1 \%$ under $50 \%$ FC. It can be referred that macronutrients uptake responded to the high rate of potassium silicate $(2 \%)$ more than the low rate $(1 \%)$ under drought stress. On the other hand, for salicylic acid treatment, the highest values of NPK uptake (117.61, 16.20 and 100.76 $\mathrm{mg} /$ plant, respectively) were recorded by salicylic acid at 200ppm under 50\% FC. It can be noticed that macronutrients uptake responded to the low rate of salicylic acid (100 ppm) more than the high rate $(200 \mathrm{ppm})$ under drought stress. The promotive effect of salicylic acid could be attributed to its bioregulator effects on physiological processes in plants such as ion uptake, cell differentiation, morphogenesis, enzymatic activities, protein synthesis and photosynthetic activity as reported by El-Tayeb (2015).
The increase in $\mathrm{N}$ uptake under drought stress (mean values) as influenced by foliar application of the studied materials could be organized in the following order: Potassium silicate 2\%> Salicylic acid $200 \mathrm{ppm}>$ Potassium silicate 1\%> Salicylic acid 100ppm > the control. Meanwhile, the mean values of $\mathrm{P}$ treatments can be arranged as follows: Potassium silicate 2\%> Salicylic acid 200ppm > Salicylic acid 100ppm > Potassium silicate 1\% > the control. While, $\mathrm{K}$ can be arranged as follows: Potassium silicate $2 \%>$ Potassium silicate $1 \%$ Salicylic acid 200 ppm>Salicylic acid 100 ppm> the Control.

3.4.Water use efficiency as affected by potassium silicate and salicylic acid under water stress

Water use efficiency (WUE) also is an important characteristic, which provides information on the adaptation potential of a plant to water stress conditions. Data in Table (5) show the effect of foliar applications by potassium silicate and salicylic acid on water use

Table (5): Effect of potassium silicate and salicylic acid on water use efficiency under water stress.

\begin{tabular}{|c|c|c|c|c|c|}
\hline \multicolumn{3}{|c|}{$1^{s t}$ experiment } & \multirow{2}{*}{$\begin{array}{c}\text { Total } \\
\text { water } \\
\text { applied } \\
\text { m }^{3} / \text { fed }\end{array}$} & \multirow{2}{*}{$\begin{array}{c}\text { Total dry } \\
\text { matter } \\
\text { kg/fed }\end{array}$} & \multirow{2}{*}{$\begin{array}{c}\text { *Water use } \\
\text { efficiency } \\
\mathbf{k g} / \mathrm{m}^{3}\end{array}$} \\
\hline \multicolumn{2}{|c|}{ Treatments } & FC \% & & & \\
\hline \multirow{4}{*}{\multicolumn{2}{|c|}{ Control }} & 100 & 1840 & 6394 & 3.48 \\
\hline & & 75 & 1380 & 5198 & 3.77 \\
\hline & & 50 & 920 & 4439 & 4.83 \\
\hline & & \multicolumn{2}{|c|}{ Mean } & 5328.77 & 4.03 \\
\hline \multirow{8}{*}{$\begin{array}{l}\text { Potassium } \\
\text { silicate } \%\end{array}$} & \multirow{4}{*}{1} & 100 & 1840 & 8855 & 4.81 \\
\hline & & 75 & 1380 & 8234 & 5.97 \\
\hline & & 50 & 920 & 5175 & 5.63 \\
\hline & & \multicolumn{2}{|c|}{ Mean } & 7421.33 & 5.47 \\
\hline & \multirow{4}{*}{2} & 100 & 1840 & 7682 & 4.18 \\
\hline & & 75 & 1380 & 9085 & 6.58 \\
\hline & & 50 & 920 & 5842 & 6.35 \\
\hline & & \multicolumn{2}{|c|}{ Mean } & 7536.33 & 5.70 \\
\hline \multirow{3}{*}{\multicolumn{2}{|c|}{ LSD at $5 \%$}} & \multicolumn{3}{|c|}{ Potassium silicate $(\mathrm{A})$} & 0.77 \\
\hline & & \multicolumn{3}{|c|}{ Moisture content (B) } & 0.53 \\
\hline & & \multicolumn{3}{|c|}{$\mathbf{A B}$} & 0.93 \\
\hline \multicolumn{3}{|c|}{$2^{\text {nd }}$ experiment } & 1840 & 7015 & 381 \\
\hline \multirow{8}{*}{$\begin{array}{c}\text { Salicylic acid } \\
\text { ppm }\end{array}$} & \multirow{4}{*}{100} & 100 & 1840 & 1015 & 3.81 \\
\hline & & 75 & 1380 & 6049 & 4.38 \\
\hline & & 50 & 920 & 5428 & 5.90 \\
\hline & & \multicolumn{2}{|c|}{ Mean } & 6164 & 4.70 \\
\hline & \multirow{4}{*}{200} & 100 & 1840 & 7130 & 3.88 \\
\hline & & 75 & 1380 & 5980 & 4.33 \\
\hline & & 50 & 920 & 4508 & 4.90 \\
\hline & & \multicolumn{2}{|c|}{ Mean } & 5872.67 & 4.37 \\
\hline \multirow{3}{*}{\multicolumn{2}{|c|}{ LSD at $5 \%$}} & & 0.09 \\
\hline & & \multicolumn{2}{|c|}{ Moisture content (B) } & & 0.15 \\
\hline & & \multicolumn{3}{|c|}{$\mathbf{A B}$} & 0.27 \\
\hline
\end{tabular}

$*$ Water use efficiency $=$ Total dry matter $\mathrm{kg} / \mathrm{fed} /$ Total water applied $\mathrm{m}^{3} / \mathrm{fed}$. 
efficiency of sorghum plants under water stress. The data clearly reveal that foliar applications of potassium silicate had the highest significant water use efficiency compared to the control. This may be due to the alleviating roles of both potassium and silicon for drought stress. These results are in agreement with those suggested by Hattori et al. (2005) who suggasted that silicon application may be useful to improve drought tolerance of sorghum via the enhancement of water uptake ability. Such results were confirmed also by the findings of Abou-Baker et al. (2011) on faba bean plants. The values in potassium silicate treatment ranged between 4.18 and $6.58 \mathrm{~kg} / \mathrm{m}^{3}$. The highest value was obtained at $2 \%$ potassium silicate under $75 \%$ FC. While, the lowest value was at $2 \%$ potassium silicate under $100 \%$ FC. Water use efficiency was significantly improved by silicon application on sorghum cultivars, (Mukhtar et al. 2011).

On the other hand, salicylic acid gave a significant effect on water use efficiency. The lowest value $\left(3.82 \mathrm{~kg} / \mathrm{m}^{3}\right)$ was recorded at 100 ppm SA under $100 \%$ FC, while the highest value $\left(5.90 \mathrm{~kg} / \mathrm{m}^{3}\right)$ was recorded at $100 \mathrm{ppmSA}$ under $50 \%$ FC. This may be attributed to the fact that foliar SA application can increase the leaf diffusive resistance and lower transpiration rates and these conclusions were recorded by Bakry et al. (2012). These results are in agreement with those obtained by Subramanian et al. (2006) who reported higher WUE in wheat and tomato under water stress than under well irrigation due to transpiration reduction. The mean values of the treatments are arranged as follows: $2 \%$ potassium silicate $>1 \%$ potassium silicate $>100$ ppm salicylic acid $>200$ ppm salicylic acid $>$ the control.

\section{Conclusion}

It could be concluded that the addition of potassium silicate and salicylic acid at rates $1 \%$, $2 \%$ and $100 \mathrm{ppm}, 200 \mathrm{ppm}$, respectively are beneficial to mitigate the adverse effects of water stress. The possible mechanism involved in the enhancement of growth parameters were due to the increase of water use efficiency of plants which in turn increased the growth. Potassium supply within this range increased significantly the macronutrients uptake of sorghum plants. Thus, further studies are needed to explore the mechanisms of improving plant growth under water stress by potassium silicate and salicylic acid through various methods involving plant species and soil.

\section{REFERENCES}

Abdel-Wahed M.S., Amin A.A. and El-Rashad S.M. (2006). Physiological effect of some bioregulators on vegetative growth, yield and chemical constituents of yellow maize plants. World J.Agric. Sci., 2 (2):149-155.

Abou-Baker A. H., Abd-Elhdl M. and Abbas M. M. (2011). Use of silicate and different cultivation practices in alleviating salt stress effect on bean plants. Austr. J. Basic and Appl. Sci., 5 (9): 769-781.

Ahmed M., Hassen F., Qadeer U. and Aslam M.A. (2011). Silicon application and drought tolerance mechanism of sorghum. Afr. J. Agric. Res. 6:594-607.

Alam S.M. (1994). Nutrient by plants under stress conditions. In: Pessarakli M. (ed.) Handbook of Plant and Crop Stress, pp. 227-246. Marcel Dekker (pub.), New York.USA.

Asgharipour M. and Heidari M. (2011). Effect of potassium supply on drought resistance in sorghum: plant growth and macronutrient content. Pak. J. Agri. Sci., 48 (3), 197-204.

Bakry B.A., El-Hariri D.M., Mervat Sh. Sadak and El-Bassiouny H.M. (2012). Drought stress mitigation by foliar application of salicylic acid in two linseed varieties grown under newly reclaimed sandy soil. J. of Appl. Sci. Res., 8(7): 3503-3514.

Beg M. and Sohrab A. (2012). Effect of potassium on moong bean. J. Life Sci. 1: 109-114.

Chanchal M., Riti T.K. and Deepak G. (2016). Alleviation of abiotic and biotic stresses in plants by silicon supplementation. Sci. Agri., 13 (2): 59-73.

Cottenie A., Verloo M., Velghe G. and Comerlynk R. (1982). Chemical analysis of plant and soil. Laboratory of analytical and Agro-Chemistry,State University, Ghent, Belgium.

Du N. W., Guo Z. X. and Wang R. (2010). Morphological and physiological responses of Vitex negundo L. var. heterophylla (Franch.) Rehd., to drought stress. Acta Physiol. Plant. 32:839-848.

El-Tayeb M.A. (2005). Response of barley grains to the interactive effect of salinity 
and salicylic acid. Plant Growth Regul., 45: 215-224.

Hattori T., Inanaga S., Hideki A., Ping A., Shigenori M., Miroslava L. and Lux A. (2005). Application of silicon enhanced drought tolerance in Sorghum bicolor. Physiol. Plant., 123, 459-466.

Janda T., Horvath E., Szalai C. and Pald E. (2007). Role of salicylic acid in the induction of abiotic stress tolerance. In: Salicylic Acid: A Plant Hormone Hayat and A. Ahmed, Springer (eds) pp. 91154. Dordrecht, Netherlands:.

Kang G.Z., Li G.Z., Liu G.Q., Xu W., Peng X.Q. and Wang C.Y. (2013). Exogenous salicylic acid enhances wheat drought tolerance by influence on the expression of genes related to ascorbate-glutathione cycle. Biol. Plant, 57:718-24.

Khatiby A., Vazin F., Hassanzadeh M. and Shadmehri A. (2016). Effect of foliar application with salicylic acid on some morphological and physiological characteristics of sesame (Sesamum indicum L.) Under drought stress. Cercetari Agronomice in Moldova, 4 (168) 35-42.

Klute A. (1986). Methods of Soil Analysis. Part 1. Physical and Mineralogical Methods $2^{\text {nd }}$ Ed., Amer. Soc. Agron. Monograph No. 9, Madison, Wisconsin,USA.

Liang Y., Shen Q., Shen Z. and Ma T. (1996). Effects of silicon on salinity tolerance of two barley cultivars. J. Plant Nutr. 19: 173-183.

Ma J.F. and Yamaji N. (2006). Silicon uptake and accumulation in higher plants. Trends Plant Sci., 11 :392-397.

Maghsoudi K., Emam Y. and Ashraf M. (2015). Influence of foliar application of silicon on chlorophyll fluorescence, photosynthetic pigments, and growth in water-stressed wheat cultivars differing in drought tolerance. Turk. J. Bot., 39: 625634.

Mali M. and Aery N.C. (2008). Silicon effects on nodule growth, dry-matter production, and mineral nutrition of cowpea (Vigna unguiculata). Plant Nutr. Soil Sci.171:835-840.

Marschner P.(2012). Mineral Nutrition of Higher Plants, $3^{\text {rd }}$ ed.; Academic Press, London, UK, pp. 178-189.
Mukhtar A., Fayyaz H., Ummara Q. and Aqeel M. (2011). Silicon application and drought tolerance mechanism of sorghum. Af. J. Agric. Res. 6(3): 594-607, 4.

Nikju M. B. (2017). Effect of salicylic acid and drought stress on crop yield. Chem. Res. J., 2(2):125-132.

Page A. L., Miller R.H. and Keeny D.R. (1982). Methods of Soil Analysis. Part $\Pi$. Chemical and microbiological properties $2^{\text {nd }}$ Ed., Amer. Soc. Agron. Monograph No. 9, Madison, Wisconsin, USA.

Raza M. A., Saleem M. F., Shah Jamil G. M., and Khan I. H. (2013). Potassium applied under drought improves physiological and nutrient uptake performances of wheat (Triticum aestivun L.) J. Soil Sci. and Plant Nutr., 13(1), 175-185.

Ruppenthal V., Zoz T., Steiner F., Lana M., and Castagnara D. (2016). Silicon does not alleviate the adverse effects of drought stress in soybean plants.Semina Ciencias Agrarias, Londrina, (37): 3941-3954.

Sangakkara U.R., Frehner, M. and Nosberger, J. (2001). Influence of soil moisture and fertilizer potassium on the vegetative growth of mungbean (Vigna radiata L.) and cowpea (Vigna unguiculata L.). J. Agron. Crop Sci., 186: 73-81.

Simaei M., Khavari-Nejad R.A. and Bernard F. (2012). Exogenous application of salicylic acid and nitric oxide on the ionic contents and enzymatic activities in $\mathrm{NaCl}$-stressed soybean plants, Amer. J. Plant Sci.,3: ,1495-1503.

Singh B. and Usha K. (2003). Salicylic acid induced physiological and biochemical changes in wheat seedlings under water stress. Plant Growth Regul., 39: 137-141.

Snedecor G. W. and Cochran W.G. (1980). Statistical Methods. $7^{\text {th }}$ ed., Iowa State Univ. Press, Ames,Iowa, USA, PP. 255269.

Sonobe K., Hattori T., An P., Tsuji W., Eneji E., Tanaka K. and Inanaga S. (2009). Diurnal variations in photosynthesis, stomatal conductance and leaf water relation in sorghum grown with or without silicon under water stress. J. Plant Nutr., 32:433442.

Stanhill G. (1987). Water use efficiency. Adv. Agron., 39: 53-85.

Subramanian K.S, Santhanakrishnan P. and Balasubramanian P. (2006) Responses of 
field grown tomato plants to arbuscular mycorrhizal fungal colonization under varying intensities of drought stress. Sci. Hort., 107: 245-253.

Taiz L. and Zeiger E. (2006). Plant physiology. $4^{\text {th }}$ Edition, Sinauer Associates, Inc., Sunderland, UK.

Tarabih M.E., El-Eryan E. E. and El-Metwally M. A.(2014). Physiological and pathological impacts of potassium silicate on storability of Anna apple fruits. Amer. J. Plant Physiol., 9(2): 52-67.

Vaculik M., lux A., luxova M., Tanimoto E. and Lichtscheidl I., (2009). Silicon mitigates cadmium inhibitory effects in young maize plants. Envi. Experi. Bot., 67: 5258.

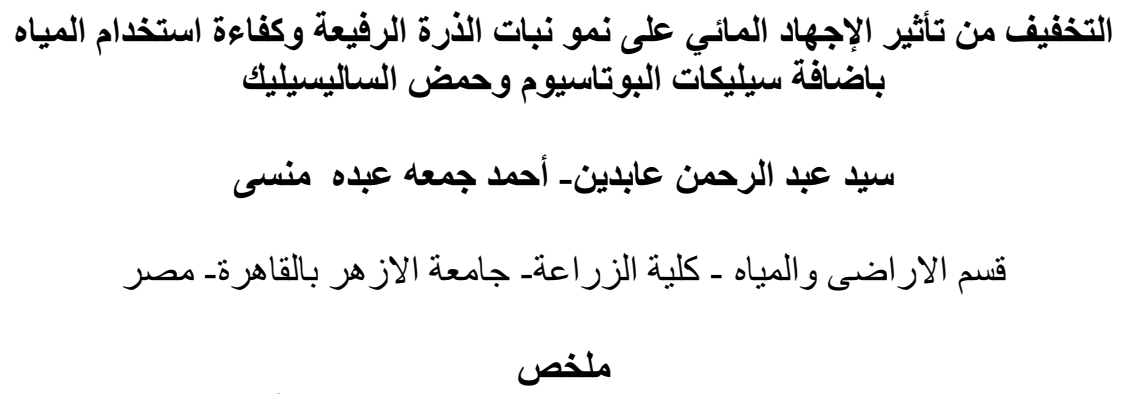

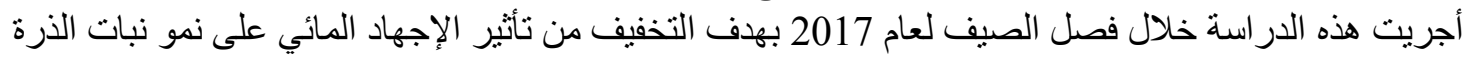

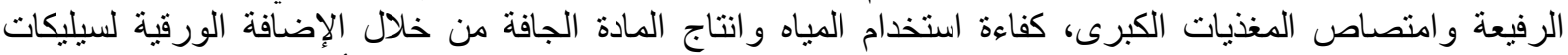

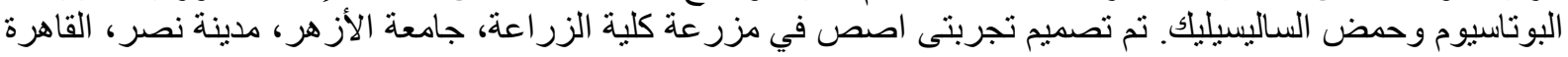

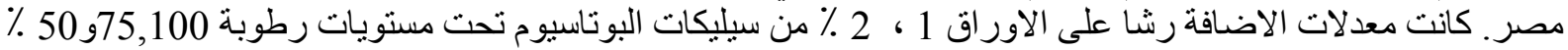

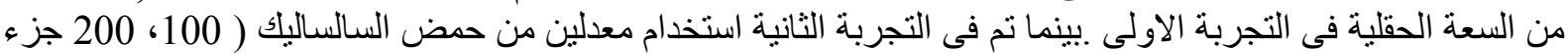

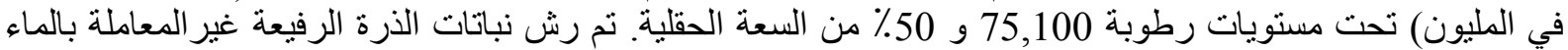

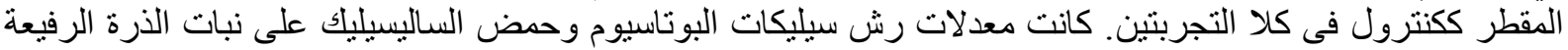

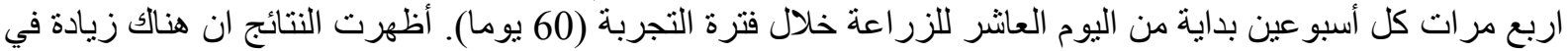

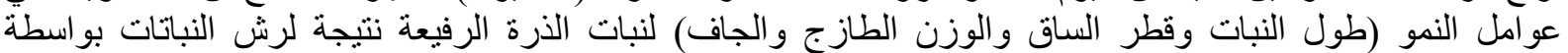

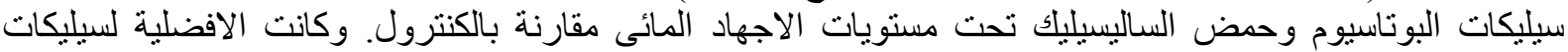

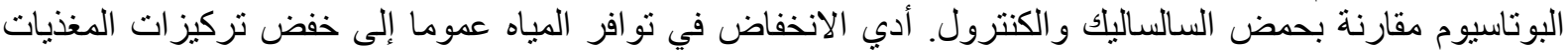

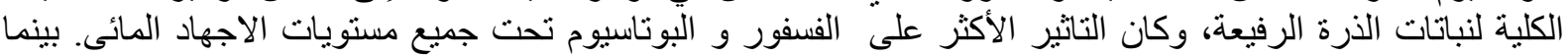

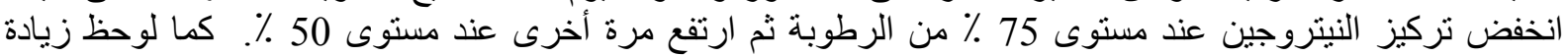

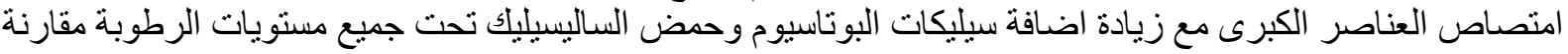

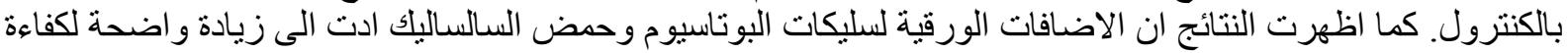

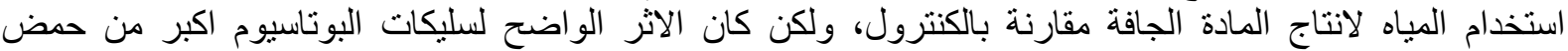

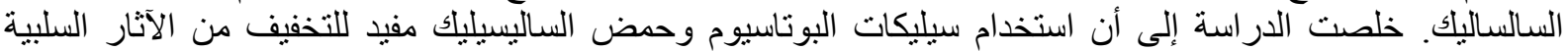

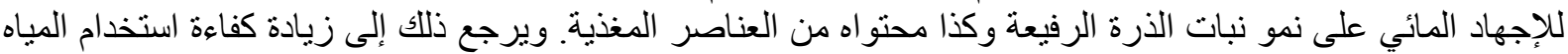

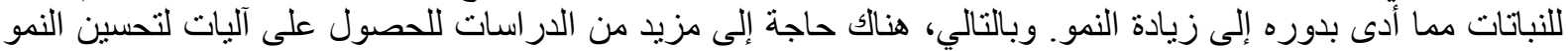

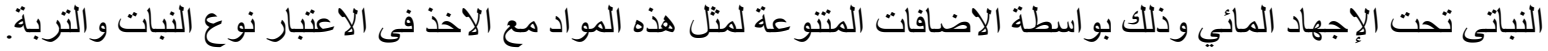

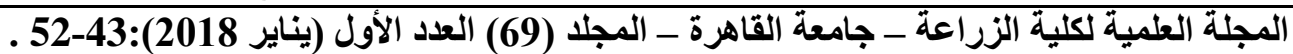

